\title{
Incremental Value Relevance of Disaggregated Book Values and Disaggregated Earnings: Evidence from Nigeria
}

\author{
Okun Omokhoje Omokhudu ${ }^{1}(\mathrm{PhD}) \&$ Peter Okoeguale Ibadin ${ }^{1}(\mathrm{PhD})$ \\ ${ }^{1}$ Department of Accounting, Faculty of Management Sciences, University of Benin, Benin City, Nigeria \\ Correspondence: Peter Okoeguale Ibadin (PhD), Department of Accounting, Faculty of Management Sciences, \\ University of Benin, Benin City, Nigeria
}

Received: September 6, 2015

Accepted: November 4, 2015

Online Published: November 16, 2015

doi:10.5430/afr.v4n4p176

URL: http://dx.doi.org/10.5430/afr.v4n4p176

\begin{abstract}
The link between accounting information and firm value has attracted the attention of accounting and finance researchers since the seminar work of Ball and Brown (1968) and Beaver (1968). The association of accounting information with firm value is value relevance research. Value relevance is the degree to which accounting information captures information impounded in stock prices. Ohlson (1995) provided the conceptual linkage between accounting information and firm value. Since then, value relevance research has increased in volume and diversity. A trend in this line of enquiry is to determine if disaggregated accounting information is incrementally value relevant beyond bottom line accounting information. The objective of this paper was to ascertain if disaggregated accounting information has more value relevance compared to bottom line measures for firms listed on the Nigerian Stock Exchange Market. We specifically investigated the value relevance of disaggregated accounting information for Nigerian listed firms, using a sample of 940 firm-years from 1994 to 2013. The study contributes to the extant value relevance literature by employing a methodology that accounts for documented inefficiencies of the Nigerian capital market. Given the analysis conducted, findings indicate that disaggregated earnings are incrementally value relevant beyond bottom line earnings. Besides, disaggregated book value is found to be more value relevant compared to book value. In the light of these findings, both investors and analysts should shift emphasis from bottom line accounting information, like earnings and book value to disaggregated accounting numbers to improve the quality of investment decisions they make. Besides, regulatory authorities must improve on the corporate governance environment in order to mitigate incidences of window dressing, creative accounting and other corporate malfeasances
\end{abstract}

Keywords: Value relevance, Earnings, Book value of equity, Ohlson model, Disaggregated accounting information Nigeria

\section{Introduction}

The fundamental thrust of value relevance studies is to determine whether accounting information contained in financial statements issued by companies is relevant to users for investment decision making. Relevance is a primary attribute of accounting information; it is the degree to which such information influences the decision making of investors. The empirical operationalisation of relevance is achieved by value relevance, which is the extent to which accounting information is associated with value. For investors, regulators and other users, the relevance of accounting information is a fundamental problem. Extant literature shows that over the last two decades, value relevance has assumed a central focus for market based accounting research (Beaver, 2002). Studies in developed markets have provided some indication that accounting information provides investors, useful information for investment decision making. Developed markets, as compared to emerging markets, are characterised differently. Accounting theory however has not taken into cognisance the peculiar nature of emerging markets, and so do not appropriately address the role of accounting information for relatively less efficient emerging markets (Lopes, 2002).

The argument that accounting information is less value relevant in emerging markets like Nigeria rests on the presence of market imperfections and rigidities. Osaze (2002) and Osamwonyi and Anikamdu (2007) rightly captured this assertion when they contended that the Nigerian Market is relatively inefficient with the presence of information asymmetry. These features however underscore the imperative of accounting information for investors in emerging markets. Markets participants have no access to other sources such as market analyst and forecast, making accounting information in financial statement the only source available to potential investors. Accounting 
researchers have endeavoured to establish a connection between information and firm value. Since the seminar work by Ball and Brown (1968), Beaver's (1968) studies in developed markets have indicated a statistical association between bottom line measures, as earnings, book value and firm value as indicated by share price or share return (Barth \& Clinch, 1996; Collins, Maydew \& Weiss, 1997; Melissa 2013, Adaramola \& Oyerinde, 2014). Emerging markets, like that of Nigeria, present a different case as there is no theoretical framework for establishing how accounting information relate with firm value (Dung, 2010). Graham (2000) argued that emerging markets reflect different socio-economic and cultural peculiarities. Hellstrom (2006) supported this position that value relevance of accounting information is lower for emerging economies than in well developed markets. The lack of other sources of credible and useful accounting information, may well introduce what Aboody, Hughes and Liu (2004) referred to as noisy trading. Thus,this leads to less value relevance of accounting information in such markets.

This study is motivated by the relatively lack of accounting research that takes cognisance of the peculiarities of accounting information in emerging markets and the unique institutional setting of Nigeria. Extant studies on value relevance in Nigeria have not addressed the issue as to how and when accounting information is impounded in share prices. This study fills this gap in value relevance studies in emerging markets; the primary thrust of this paper is to establish if disaggregated earnings and book values are incrementally value relevant to bottom line earnings and book values for listed firms on the Nigerian Stock Exchange floor. This study makes a contribution to empirical literature on value relevance of accounting information, by providing evidence from relatively inefficient markets in the Nigerian capital market. In order to achieve this, the paper employs the methodology that allows for accounting information to be impounded into share prices by the Market.

Following the introduction, the paper is organized as follows. Section 2 presents a review of relevant and related literature that examines value relevance of disaggregated accounting information compared to bottom line measures. Section 3 describes the methodological support for the study. Section 4 illustrates the empirical results from the study and the last section is dedicated to concluding remarks, and recommendations.

\section{Review of Related Literature and Hypotheses Development}

\subsection{Value Relevance of Disaggregated Book Values and Earnings}

The preponderance of extant literature on value relevance focuses on the bottom line metrics of earnings and book value. For instance, Kwon (2009) investigated the relative incremental value relevance of book value, earnings and cash flow. Employing the framework by Myers (1977), Ohlson (1995) and Feltham and Ohlson (1995), Kwon (2009) segregated the sample used into profit and loss firms and earnings managed and non-earnings managed firms in order to observe changes in value relevance over the period 1994-2005. Kwon's (2009) finding showed that book value is the most value relevant variable, followed by cash flow, with earnings being the least value relevant variable. Babalola (2012) investigated the value relevance of accounting information in corporate Nigeria, employing a sample of 440 firm-years. They provided evidence that earnings are more value relevant than book values. In a similar setting, Angar and Malizu (2015) investigated the relationship between earnings and changes in earnings with stock returns in the Nigerian Stock Market(NSE). Using a sample of 440 firm-years, they provided evidence that accounting information has significant relationship with stock returns in the NSE.

Beyond the shores of Nigeria, Melissa (2013) examined the relationship between share prices and accounting variables of earnings, dividends and book values for companies listed on the Nairobi Stock Exchange (NSE) market. Using a panel data analysis, they documented evidence that accounting information is significantly and positively related to share prices, and that, compared to earnings and book values, dividends have more explanatory power. Similarly, Shehzad and Ismail (2014) examined the value relevance of accounting information in the banking sector of Pakistan. Using a sample of 19 private banks over the period 2008 to 2012, they found that earnings are more value relevant than book values.

In disaggregating earnings into the component parts, the discretion of management and accountants in the context of relevant accounting standards and legislature determines the nature and extent of disaggregation. Earnings can be disaggregated into accruals and cash flow components, and also disaggregated into abnormal and normal components. Ramakrishnan and Thomas (1998), segregating earnings into permanent and transitory and unexpected earnings components, showed that the different components result in different valuation implications. Landsman, Miller and Yeh (2007) demonstrated that other earnings items are more value relevant than extraordinary and special items. Dhaliwal, Subramamyan and Trezevant (1999) and Landsman, Miller and Yeh (2007) argued and demonstrated that extraordinary and special items are less value relevant than other earnings items. The lack of relevance of some line items in generally acceptable accounting principles (GAAP) financial statements have propelled focus of analysts on "street" earnings numbers (Bradshaw \& Sloan, 2002). 
Choi, Lin, Walker and Young (2007) provided evidence that analysts proxy sustainable earnings utilized in value forecast conform more closely to non-GAAP earnings. Pope (2005) argued that where earnings components do not aggregate to fully informative bottom earnings, the precision of intrinsic value could be increased by information from income statement line. Ohlson and Penman (1992), using various components of earnings, such as gross profit, operating expenses, depreciation expenses, tax expenses and other income or expense as items as regressors, showed that different line items have variations with respect to their valuation implications. They found that the disaggregation of income data increases the explanatory power of the model. They further argued that empirical evidence is largely in consonance with economic equivalence in line items.

Some studies have examined the value relevance of earnings segregated into foreign and domestic components. The persistence of foreign earnings is more understated with respect to persistence by investors, primarily because of the perceived risk of earnings generated from different markets other than that of the investor. Thomas (2005) argued that foreign earnings, compared to domestic earnings, have lower earnings response coefficient (ERC). The growth opportunities relative to mature domestic markets, is such that investors place higher weights on earnings from foreign markets compared to domestic markets when valuing companies (Bodnar, Hwang \& Weintrop, 1997). Hope and Kang (2005) however did not subscribe to the conclusions of Bodnar \& Weintrop (1997), arguing that the conclusion from their study might be due to misspecification problems in their model. They contended that the regression specification may suffer from omitted variable issues if what they referred to as 'other information' is excluded from the model. The 'other information' exclusion results in greater bias in foreign earnings than in domestic earnings and that controlling for other information shows that foreign income is not incrementally relevant compared to domestic earnings.

Apergis and Sorros (2009) examined the impact of disaggregated earnings on stock prices for listed shipping firms. Using a sample of 36 listed shipping firms from 2000 to 2008 and employing panel cointegration and panel causality tests, and disaggregating earnings into operating and non-operating components, the study found that both types of earnings were positively related to stock prices. Chen and Wang (2004) investigated the value relevance of operating and below-the-line items in the Chinese Stock Market. They provided evidence that that earnings response coefficient is larger for below-the-line-item than for operating income.

On the disaggregation of book value into components, Ohlson and Penman (1992) examined the incremental value relevance of the disaggregated book value relative to summary book value. They found that disaggregation of book value does not improve the value relevance of the accounting information. Lev and Thiagarajan (1993) examined the incremental value relevance of a set of financial variables (or fundamentals) indicated as useful in equity valuation by security analysts. They provided evidence that disaggregated values, such as closing stock and debtors are in fact negatively related to share prices. Landsman (1986) examined aggregated book value, a study replicated by Ibrahim et al (2002) who disaggregated book value into total assets (TA) and total liabilities (TL). They found that disaggregated book value provides incremental value relevant information over aggregated book value.

Aggregated book value is made up of many components. It can be broken down into tangible non-current assets (TNCA), intangible assets (ITA), current assets (CA) and current liabilities (CL). Aggregated earnings can be broken down into turnover (TO) cost of sales and operating expenses (COP), depreciation (DEP), finance cost (FC) and tax expense (TE). Focusing on earnings components, Xu and Cai (2005) used equity valuation models that incorporated disaggregated earnings into ordinary profit, extraordinary profit and income taxes, whereas Ballas (1996) disaggregated earnings into operating income, net financing expenses, exceptional income, depreciation and tax expenses. Ohlson and Penman (1992) disaggregated earnings into gross margin, operating expense, depreciation and amortisation, taxes, extraordinary items and other items. Ling and Yao (2005) decomposed earnings into gross profit, marketing expenses, $R \& D$, operating expenses and other expenses. These items are found relevant in explaining market values of the firms.

In the context of the extant literature, this study hypothesizes that as earnings and book values are split into their component parts, the value relevance of accounting information would exceed that of bottom line earnings and book values. Consequently, the hypotheses are thus presented:

$H_{I}$ : Decomposition of earnings into their components, provide incremental value relevant information beyond bottom line earnings.

$\mathrm{H}_{2}$ : Decomposition of book value into components provides incremental value relevant information beyond bottom line book value. 


\section{Methodology and Data}

All firms quoted on the Nigerian Stock Exchange market each year from 1994 to the year 2013 constituted the population of this study. As at December, $31^{\text {st }} 2013$, the number of firms listed on the floor of the first-tier Market was 203. The choice of quoted firms derives from the basic thrust of this study, which is to determine the extent to which accounting information summarizes events that are incorporated in share prices. A defining feature of the population is that it is composed of firms subject to more stringent regulations than unquoted firms. Banks, for example are supposed to subscribe to a code of corporate governance issued by the Central bank of Nigeria. The companies in the population have their financial statements audited and made public for access by the investing public.

A sample of 940 firm-years was selected over the period 1994 to 2013. The sample selection was based on the criteria of the availability of the financial statement of sample period in any year. In order to eliminate survivability bias, we selected firms whose financials were available over the period under consideration and satisfied the following conditions:

- Sample company must be listed each year over the period 1994 to 2013

- The financial year end of the sample companies must be December, 31 .

- The firm has published its complete financial statement for the twenty year period from 1994 to 2013

- To ensure some homogeneity of information, firms in banking and insurance sectors were excluded.

- The shares of sample companies must be actively traded in the period under consideration

\section{Model Specification and Data Analysis}

\subsection{Model Specification}

The study employed four estimation techniques in order to robustly determine the incremental value relevance of disaggregated accounting information for listed firms in the NSE. We used the pooled and panel least square estimation and the dynamic models of random and fixed effects models. The Hausman test was conducted to determine which of the effects models was more appropriate. The approach utilised to address the inefficiency of the Market, is the one suggested by Dung (2010), allowing the Market to impound accounting information in share values, the dependent variable. In this nexus, this study took the dependent variable at three and six months after the firm's year end.

The decomposition of earnings into components, provide incremental value relevant information beyond bottom line earnings. We compared the $\mathrm{R}^{2}$ bar from the following equation shown below:

$$
\begin{aligned}
& \mathrm{P}_{\mathrm{jt}}=\alpha_{0}+\alpha_{1} \mathrm{EPS}_{\mathrm{jt}}+\alpha_{2} \mathrm{BVPS}_{\mathrm{jt}}+\varepsilon_{\mathrm{jt}} \\
& \mathrm{P}_{\mathrm{it}}=\beta_{0}+\beta_{1} \mathrm{BVPS}_{\mathrm{jt}}+\beta_{2} \mathrm{TOPS}_{\mathrm{jt}}+\beta_{3} \operatorname{COSPS}_{\mathrm{jt}}+\beta_{4} \mathrm{DEPPS}_{\mathrm{jt}}+\beta_{5} \mathrm{FCPS}_{\mathrm{jt}}+\beta_{6} \mathrm{TXEPS}_{\mathrm{jt}}+\varepsilon_{\mathrm{jt}}
\end{aligned}
$$

Where $P_{j t}$ is the share price of firm $j$ at 3 and 6 months end of accounting year. The $\operatorname{EPS}_{\mathrm{jt}}$ is the reported earnings per share of firm $\mathrm{j}$ for the year t. BVPS $\mathrm{j}_{\mathrm{jt}}$ is the book value per share of firm $\mathrm{j}$ at the end of year $\mathrm{t}$. TOPS $_{\mathrm{jt}}$ is the turnover per share of firm $j$ at the end of year t. COSPS $j$ is the cost of sales and operating expenses of firm $j$ at the end of year. DEPPS $_{j \mathrm{t}}$ is depreciation expenses per share of firm $\mathrm{j}$ at the end of year $\mathrm{t} . \mathrm{FCPS}_{\mathrm{jt}}$ is finance expense of firm $\mathrm{j}$ at the end of year $t$. TXEPS ${ }_{\mathrm{jt}}$ is the tax expense of firm $\mathrm{j}$ at the end of year $\mathrm{t}$.

The Hypotheses can be restated as follow

$\mathrm{H}_{0}: \mathrm{R}^{2}$ bar from bottom line earnings $=\mathrm{R}^{2}$ bar from Decomposed earnings

$\mathrm{H}_{1}: \mathrm{R}^{2}$ bar from Decomposed earnings $>\mathrm{R}^{2}$ bar from Bottom line earnings

The decomposition of book value of equity into components, provide incremental value relevant information beyond bottom line book value. We compared the $\mathrm{R}^{2}$ bar from the following equation shown below

$$
\begin{aligned}
& \mathrm{P}_{\mathrm{jt}}=\delta_{0}+\delta_{1} \mathrm{EPS}_{\mathrm{jt}}+\delta_{2} \mathrm{BVPS}_{\mathrm{jt}}+\varepsilon_{\mathrm{jt}} \\
& \mathrm{P}_{\mathrm{it}}=\alpha_{0}+\alpha_{1} \mathrm{EPS}_{\mathrm{jt}}+\alpha_{2} \mathrm{TNCAPS}_{\mathrm{jt}}+\alpha_{3} \mathrm{CAPS}_{\mathrm{jt}}+\alpha_{4} \mathrm{CLPS}_{\mathrm{jt}}+\varepsilon_{\mathrm{jt}}
\end{aligned}
$$

Where TNCAPS $S_{j t}$ is total non-current assets per share for firm $\mathrm{j}$ in time t. CAPS $\mathrm{j}_{\mathrm{jt}}$ is current assets per share for firm $\mathrm{j}$ in time t. CLPS ${ }_{\mathrm{jt}}$ is current liability per share for firm $\mathrm{j}$ in time $\mathrm{t}$

The Hypotheses can be restated as follow

$\mathrm{H}_{20}: \mathrm{R}^{2} \mathrm{BVPS}=\mathrm{R}^{2}$ Decomposed book value 
$\mathrm{H}_{21}: \mathrm{R}^{2}$ Decomposed book value $>\mathrm{R}^{2} \mathrm{BVPS}$

4.2 Data Analysis and Discussion of Results

\subsubsection{Descriptive Analysis}

The data used in the analysis consist of 47 firms listed in the Nigerian Stock Exchange from 1994 to 2013, a period of twenty years. The sample covered all industries excluding firms in financial industry. Table 1 provides a summary of statistics of non-financial firms based on the industry sector class in the Nigerian Stock Exchange. The accounting data were collected primarily from the financial statements of the sample firms, Nigerian Stock Exchange Fact books and Nigerian Stock Exchange daily price quotations.

Share price data 3 and 6 months after sample firm year end were collected daily from share price quotation. Accounting data extracted from financial statements and supplemented by NSE fact book.

Table 1. Descriptive statistics for non-financial firms (Observations=150)

\begin{tabular}{llllll}
\hline & Mean & Median & Maximum & Minimum & Std. Dev. \\
\hline BVPS & 5.020503 & 3.04255 & 192.457 & -91.27766 & 10.13671 \\
CAPS & 11.77786 & 5.422066 & 301.4204 & -1.624977 & 20.40002 \\
CFOPS & 1.696384 & 0.529118 & 37.28344 & -9.902525 & 4.18497 \\
CLPS & 10.61086 & 4.590296 & 192.9318 & 0.099883 & 18.19554 \\
COSPS & 19.5776 & 5.915835 & 466.1418 & 0 & 43.21944 \\
DEPPS & 0.548857 & 0.249695 & 8.726067 & 0 & 0.825392 \\
DPS & 62.68745 & 12.5 & 3600 & -16.8 & 179.6574 \\
EPS & 1.038793 & 0.40598 & 33.82083 & -94.60538 & 4.162596 \\
FCPS & 0.642632 & 0.269215 & 18.76786 & -0.865496 & 1.294847 \\
SHP1 & 16.55206 & 3.96 & 300.98 & 0.50 & 34.70247 \\
SHP2 & 17.41489 & 3.98 & 360 & 0.50 & 37.45007 \\
TNCPS & 6.897075 & 2.603407 & 189.0476 & 0.177199 & 16.55171 \\
TOPS & 25.37964 & 8.773375 & 525.9461 & 0 & 51.04428 \\
TXEPS & 22.55048 & 0.000778 & 622.9417 & -21.30265 & 67.9041
\end{tabular}

Table 1 reports the descriptive statistics for sample over a period of 20 years from 1994 to 2013. The turnover per share (TOPS) shows mean of 25.47. with a standard deviation of 51.58. Cost of sales and operating expenses per share (COSPS) with and mean value of 19.59 and a standard deviation of 43.68. The earnings per share (EPS) over the period with the average earning per share is 1.21 and a standard deviation of 2.81. Depreciation Expense per share (DEPPS) mean value stands at 0.54 and a standard deviation of 0.78 . Finance cost per share (FCPS) shows with an average value of 0.61 and a standard deviation of 1.14. Share price at 3 months after year end (SHP1) with mean and standard deviation are N16.6 and N34.7 respectively. Share price at 6 months after year end (SHP2) has a mean and standard deviation of N17.4 and N37.4 respectively. Tax expense per share (TXEPS) reveals a mean value of 22.74 and a standard deviation of 68.53. The mean DPS is 63.6kobo per share. Standard deviation of this variable is $181.5 \mathrm{k}$. With respect to cash flow per share (CFOPS) the maximum recorded in the period was N37.28 and the lowest was N-9.90. The average stood at N1.72, with standard deviation at N4.13. Book value per share (BVPS) has a mean value in period of N5.22 and a standard deviation of N9.82. The mean Total Non-current asset per share (TNCPS) was N6.96 and its standard deviation at N16.74. For current asset per share (CAPS) mean value was N11.83 and the standard deviation at N20.69. 
Table 2 .

\begin{tabular}{|c|c|c|c|c|c|c|c|c|}
\hline & \multicolumn{4}{|c|}{$\begin{array}{l}\mathrm{P}_{\mathrm{jt}}=\alpha_{0}+\alpha_{1} \mathrm{EPS}_{\mathrm{jt}}+\alpha 2 \mathrm{BVPSjt}+\varepsilon_{\mathrm{jt}} \\
\text { Dependent Variable SHP1 }\end{array}$} & \multicolumn{3}{|c|}{ Dependent Variable SHP2 } & \multirow[b]{2}{*}{ FEM } \\
\hline & $\begin{array}{l}\text { POOLED } \\
\text { OLS }\end{array}$ & $\begin{array}{l}\text { PANEL } \\
\text { OLS }\end{array}$ & REM & FEM & $\begin{array}{l}\text { POOLED } \\
\text { OLS }\end{array}$ & $\begin{array}{l}\text { PANEL } \\
\text { OLS }\end{array}$ & REM & \\
\hline EPS & 0.76 & 0.38 & $1.69 * *$ & $1.42 * *$ & 3.11 & $0.41 * *$ & $1.92 * *$ & $1.43 * *$ \\
\hline & -1.61 & -2.39 & -6.61 & -5.47 & -0.09 & -2.72 & -2.86 & -5.47 \\
\hline$B V P S$ & -0.07 & -0.17 & $0.14 * *$ & 0.12 & 0.11 & $-0.26 * *$ & 0.14 & 0.12 \\
\hline$F$-stat & $402.4^{* *}$ & $573.8 * *$ & $32.64 * *$ & $14.48 * *$ & $69.2 * *$ & $765.86^{* *}$ & $37.6 * *$ & $14.5^{* *}$ \\
\hline P-value & 0 & 0 & 0 & 0 & 0 & 0 & 0 & 0 \\
\hline $\begin{array}{l}\text { (Hausman } \\
\text { TESt) }\end{array}$ & & & $\chi^{2(2)}$ & & & & & $\chi^{2(2)}$ \\
\hline $\begin{array}{l}\text { (Comparing } \\
\text { Effect) }\end{array}$ & & & $45.01 * *$ & & & & & $45.01 * *$ \\
\hline
\end{tabular}

The above Table 2 shows earnings having a positive relationship with the dependent variable share price at 3 months and 6 months after year end. Using Pooled, Panel, Random effect and Fixed effect model (t-statistics=1.61, 2.39, 6.61 and 5.47) and (P-values $=00.11,0.02,0.00$ and 0.00$)$ at Shp1. The result show strong positive relationship of earnings with share price, except for pool estimation. At Shp2 using Pooled, Panel, Random effect and Fixed effect model (t-statistics=0.09, 2.72, 2.86 and 5.47) and (P-values $=0.09,0.006,0.004$ and 0.00). Earnings are positively associated with value and significantly too, except under the pool estimation.

The results from book values, using the pool and panel estimation are inconsistent with dynamic models of Random Effect and Fixed Effect model. Using the pool and panel (t-statistics $=-0.41$ and -2.68$)$ and $(\mathrm{P}$-values $=0.68$ and $0.01)$, at shp1. At shp2 using the pool and panel least square estimation (t-statistics 0.86 and -4.24$)$ and $(\mathrm{P}$-values $=$ 0.86 and -4.24). This result shows a negative relationship between book values and share price, significant under Panel estimation, but not under Pool estimation. The Random effect and Fixed effect model have (t-statistics $=1.38$ and 1.12) and (P-values $=0.17$ and 0.26) at SHP1. At shp2 (t-statistics $=0.63$ and 1.12) and $(\mathrm{P}$-values $=0.52$ and 0.26). The dynamic models show that book value is positively related with share price but insignificantly so. We observed the lack of consistency of result from the estimation methods. The $\mathrm{R}^{2}$ ranges from $6.5 \%$ under the REM to 65.9 under the Panel least square at shp1. At $\operatorname{shp} 2 \mathrm{R}^{2}$ ranges from 7.5\% under REM to 72.3 under Panel least square. The F-statistics on all four estimation and at both share prices shows the significance of the model. 
Table 3. Value relevance of disaggregated Book value of equity

\begin{tabular}{|c|c|c|c|c|c|c|c|c|}
\hline & \multicolumn{3}{|c|}{$\begin{array}{l}\mathbf{P}_{\mathrm{it}}={ }_{0}+{ }_{1} \mathrm{EPS}_{\mathrm{jt}}+{ }_{2} \mathrm{TNCAPS}_{\mathrm{jt}}+ \\
\text { Dependent Variable SHP1 }\end{array}$} & CCAPS $_{\mathrm{jt}}+$ & \multicolumn{4}{|c|}{$\begin{array}{l}{ }_{4} \mathrm{CLPS}_{\mathrm{jt}} \\
\text { Dependent Variable SHP2 }\end{array}$} \\
\hline & $\begin{array}{l}\text { POOLED } \\
\text { OLS }\end{array}$ & $\begin{array}{l}\text { PANEL } \\
\text { OLS }\end{array}$ & REM & FEM & $\begin{array}{l}\text { POOLED } \\
\text { OLS }\end{array}$ & $\begin{array}{l}\text { PANEL } \\
\text { OLS }\end{array}$ & REM & FEM \\
\hline \multirow[t]{2}{*}{ Intercept } & 13.76 & 21.4 & 9.02 & 10.9 & 8.28 & 44.8 & 8.73 & 10.64 \\
\hline & -4.75 & -8.88 & -7.22 & -10.23 & -4.83 & -3.3 & -6.65 & -9.56 \\
\hline \multirow[t]{2}{*}{ EPS } & 0.66 & 0.19 & $2.58 * *$ & $1.53 * *$ & $3.43^{*}$ & 0.24 & $2.82 * *$ & $1.73 * *$ \\
\hline & -1.77 & -1.04 & -10.1 & $(5.720$ & -2.24 & -1.51 & -10.7 & -6.24 \\
\hline \multirow[t]{2}{*}{ TNCPS } & -0.21 & 0.22 & $0.29 * *$ & -0.09 & $-0.43^{* *}$ & 0.06 & $-0.32 * *$ & -0.12 \\
\hline & $(-2.04)$ & -0.08 & -3 & $(-1.02)$ & $(-3.24)$ & -0.62 & $(-3.72)$ & $(-1.31)$ \\
\hline \multirow[t]{2}{*}{ CAPS } & $0.08 * *$ & -0.03 & $-0.29 * *$ & -0.12 & -0.32 & -0.07 & $-0.29 * *$ & -0.11 \\
\hline & 0.77 & -0.71 & $(-2.79)$ & $(-1.06)$ & -0.93 & $(-0.94)$ & $(-2.75)$ & $(-1.02)$ \\
\hline \multirow[t]{2}{*}{ CLPS } & $0.25^{*}$ & -0.15 & $0.96 * *$ & $0.57 * *$ & $1.16^{* *}$ & 0.05 & $1.06 * *$ & $0.67 * *$ \\
\hline & -2.37 & $(-1.41)$ & 9.39 & $5.01)$ & -3.06 & -0.51 & -9.99 & -5.65 \\
\hline$R^{2}$ & 57 & 69.6 & 19.7 & 46.8 & 29.7 & 71.7 & 22.2 & 49.3 \\
\hline $\operatorname{Adj} R^{2}$ & 56.7 & 67.7 & 19.4 & 43.7 & 29.2 & 71.5 & 21.8 & 46.5 \\
\hline$F$-stat & $247.4^{* *}$ & $37.8^{* *}$ & $57.5^{* *}$ & $15.6 * 8$ & $78.3 * *$ & $446.5^{* *}$ & $66.3 * *$ & $17.3^{* *}$ \\
\hline P-value & 0 & 0 & 0 & 0 & 0 & 0 & $(0.000$ & 0 \\
\hline \multicolumn{4}{|c|}{ (Hausman TESt) } & $\chi^{2(4)}$ & & & & $\chi^{2(4)}$ \\
\hline \multicolumn{4}{|c|}{ (Comparing Effect) } & $178.2^{* *}$ & & & & $182.9 * *$ \\
\hline
\end{tabular}

** and $*$ statistically significant at $1 \%$ and $5 \%$ respectively

The above Table shows the result of the regression when we disaggregate of book value. The result shows that EPS is significantly and positively associated with share prices under REM and FEM, with (t-statistics= 10.1 and 5.72) and associated (P-values $=0.00 .00$ and 0.00$)$ at shp1. The result at shp2 follow the same pattern, with the coefficient of earnings been significant even at $1 \%$ level. Under the Pool and Panel Least Square however, the result largely point to the insignificance of earnings, though still positively associated with share prices.

Total Non-current assets per share reveals different picture. It is positively and significantly associated with share price under the REM, with (t-statistics $=3.00$ and $\mathrm{p}$-value of 0.00 ) at shp1 and at shp2 (t-statistics=-3.72 and $\mathrm{p}$-value $=0.00)$. The result of FEM indicates negative association with share values, but not significant ( $\mathrm{t}$-stat=--1.02 and $\mathrm{p}$-value $=0.31)$ at shp1 and ( $\mathrm{t}$-stat=-1.31 and $\mathrm{p}$-values $=0.19)$ at shp2. Under the Panel estimation non-current asset is positively associated with share price but not significant. Current asset per share (CAPS) is positively related to share price under the Effect models but negatively associated under the Pool and Panel Least Square. The coefficients under REM are significant ( $\mathrm{t}$-stat=-2.79 and $\mathrm{p}$-values $=0.005)$ at SHP1 while at SHP2 ( $\mathrm{t}$-stat $=-2.75$ and $\mathrm{p}$-values $=0.00$ ). Using the other estimation techniques, it is observed that current asset is not significantly associated with share price. On current Liability per share (CLPS), there is consistent positive and significant association with share price under Pool, REM and FEM. The ( $\mathrm{t}$-statistics=1.06, 9.39 and 5.01) and (P-values=0.029, 0.00 and 0.00) at SHP1. The result for SHP2 ( $\mathrm{t}$-statistics=3.06, 9.99 and 5.65) and $(\mathrm{P}$-values $=0.002,0.00$ and 0.00$)$.

The Adj $\mathrm{R}^{2}$ from the estimation techniques shows REM has the lowest at 19.7 and Panel Least Square at 67.7 at SHP1. The $\mathrm{R}^{2}$ at SHP2 shows REM with the lowest value of 29.9 and Panel Least Square estimation with 71.5. The F-stats. across all the four estimation techniques indicate the significance of the model and the joint significance of the variables. 
Table 4. Value relevance of disaggregated earnings

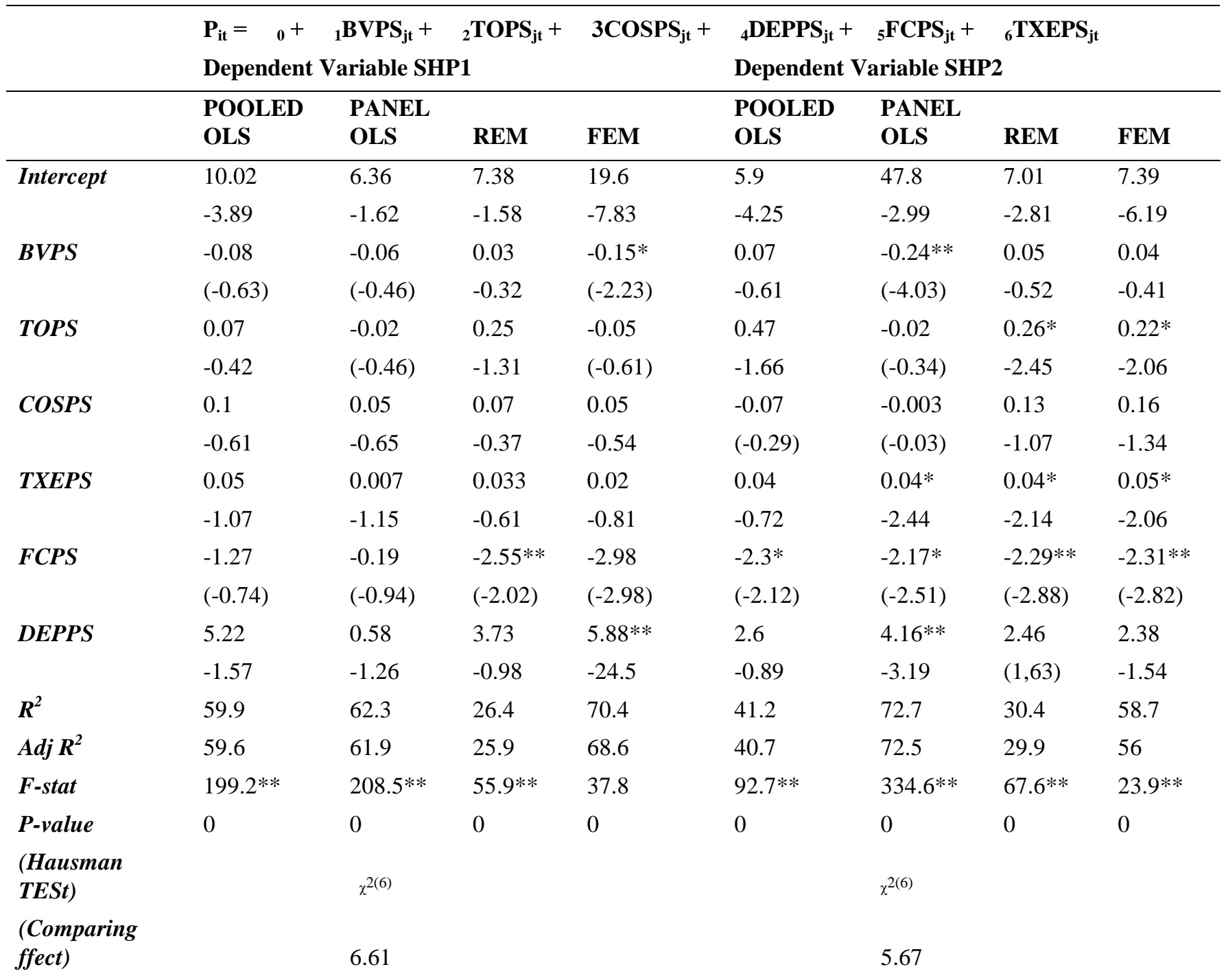

From the above Table, book value at SHP1 is not significantly associated with share price, using the Pool, PEM and REM, with (t-statistics=-0.63,-0.46 and 0.32) and (P-values-0.53, 0.64 and 0.75) respectively. At SHP2 the relationship between book values and share price is not significant using Pool, REM and FEM, with ( $\mathrm{t}$-statistics=0.61, 0.52 and 0.41$)$ and (P-values=0.54, 0.6 and 0.68) respectively. Turnover per share (TOPS) at SHP1 shows both negative and positive association with share prices, but the relationship is not significant. However at SHP2, turnover is significant under REM and FEM, with (t-statistics=2.45 and 2.06) and (P-values $=0.014$ and 0.04$)$ respectively. Since the variable is not consistently significant at the two levels of share price under the four estimation method, it is inferred that turnover is not significantly related to share price.

Cost of sales per share (COSPS) is consistently positively related to share price, though the relationship does not pass the test of significance as t-statistics indicate that the coefficient fail the test of significance at 5\% level. The same scenario is demonstrated as shp2, were the coefficient estimates are not significant under the four estimation technique.Tax expense per share (TXEPS) at SHP1 shows that the relationship with share price is positive but not significant under the four estimation techniques. At SHP2 TXEPS is positively associated with share price and significant under Panel, REM and FEM, with ( $\mathrm{t}$-statistics $=2.44,2.14$ and 2.06) and (P-values=0.02,0.02 and 0.04) respectively. Finance cost per share (FCPS) indicates positive and significant association with share price at SHP1 and SHP2 under REM and FEM. At SHP1 the relationship is not significant but it is significant at 5\% level a shp2 using Pool and Panel Least Squares, with (t-statistics=-2.12 and -2.51) and (P-values =0.03 and 0.015) respectively.

The variable Depreciation per share (DEPPS) is only significant under REM with (t-statistics =24.5 and p-values=0.00) at SHP1 and at SHP2, it is significantly related to share price using the Panel Least Square, with 
(t-statistics $=3.19$ and $p$-values=0.001). Using the other estimation methods at SHP1 and SHP2, the results indicate a consistent lack of significance in the relationship between depreciation and share price. Further, the Adj $R^{2}$ under the four methods has a minimum of 25.9 under REM and a maximum of 68.6 under FEM at shp1. The $\mathrm{R}^{2}$ at shp2 shows the minimal value of 30.4 under REM and a maximum value of 72.7 under the Panel Least Squares. The F-stats. under all estimation methods at both levels of share price indicate the joint significance of the variable in explaining share prices.

Table 5. A comparison of $\mathrm{R}^{2}$ under the four estimation techniques of earnings and disaggregated earnings at SHP1 and SHP2

\begin{tabular}{|c|c|c|c|c|c|c|c|c|c|c|c|}
\hline & & SHP1 & & & & & & SHP2 & & & \\
\hline & Pool & Panel & REM & FEM & MEAN & & Pool & Panel & $\begin{array}{l}\mathbf{R E} \\
\mathbf{M}\end{array}$ & FEM & MEAN \\
\hline & $\begin{array}{l}\text { adj } \\
\mathbf{R}^{2}\end{array}$ & $\begin{array}{r}\text { Adj } \\
\mathbf{R}^{2}\end{array}$ & $\begin{array}{l}\text { adj } \\
\mathbf{R}^{2}\end{array}$ & $\begin{array}{l}\text { adj } \\
\mathbf{R}^{2}\end{array}$ & $\operatorname{adj} R^{2}$ & $\operatorname{adj} R^{2}$ & $\begin{array}{l}\text { adj } \\
\mathbf{R}^{2}\end{array}$ & $\begin{array}{l}\text { adj } \\
\mathbf{R}^{2}\end{array}$ & $\begin{array}{l}\text { adj } \\
\mathbf{R}^{2}\end{array}$ & $\begin{array}{l}\text { adj } \\
\mathbf{R}^{2}\end{array}$ & $\operatorname{adj} R^{2}$ \\
\hline EPS & 56.2 & 65.8 & 6.3 & 40.8 & 42.3 & EPS & 17.9 & 72.1 & 7.3 & 40.1 & 34.4 \\
\hline $\begin{array}{l}\text { Disaggreg } \\
\text { ated EPS }\end{array}$ & 59.6 & 61.9 & 25.9 & 68.6 & & $\begin{array}{l}\text { Disaggre } \\
\text { gated } \\
\text { EPS }\end{array}$ & 40.7 & 72.5 & 29.9 & 56 & 49.8 \\
\hline
\end{tabular}

The Table above shows a comparison of Adj $\mathrm{R}^{2}$ under the four estimation techniques of earnings and disaggregated earnings at SHP1 and shp2. The mean Adj R ${ }^{2}$ at SHP1 is 42.3 for earnings and 54 for disaggregated earnings at SHP1. The mean Adj $\mathrm{R}^{2}$ at SHP2 is 34.4 for earnings and 49.8 for disaggregated earnings. In the context of the foregoing, the null hypothesis is rejected while the alternate hypothesis that disaggregated earnings is more value relevant than bottom line earnings is accepted.

Table 6 . The comparative mean adj $\mathrm{R}^{2}$ of book values and disaggregated book values under the four estimation methods at SHP1 and SHP2

\begin{tabular}{|l|l|l|l|l|l|l|l|l|l|l|l|}
\hline & & SHP1 & & & & & & SHP2 & & & \\
\hline & Pool & Panel & REM & FEM & MEAN & & Pool & Panel & REM & FEM & MEAN \\
\hline & $\operatorname{adj}^{2}$ & $\operatorname{adj}^{2}$ & $\operatorname{adj}^{2}$ & $\operatorname{adj}^{2}$ & $\operatorname{adj}^{2}$ & & adj $R^{2}$ & $\operatorname{adj}^{2}$ & $\operatorname{adj}^{2}$ & $\operatorname{adj}^{2}$ & $\operatorname{adj}^{2}$ \\
BVPS & 56.2 & 65.8 & 6.3 & 40.8 & 42.3 & BVPS & 17.9 & 72.1 & 7.3 & 40.1 & 34.4 \\
\hline $\begin{array}{l}\text { Disagr } \\
\text { egated } \\
\text { BVPS }\end{array}$ & 56.7 & 67.7 & 19.4 & 43.7 & 46.9 & $\begin{array}{l}\text { ated } \\
\text { BVPS }\end{array}$ & 29.2 & 71.5 & 21.8 & 46.5 & 42.3 \\
\hline
\end{tabular}

The Table above shows the mean adj $\mathrm{R}^{2}$ of book value and disaggregated book values under the four estimation methods at SHP1 and SHP2. The result shows that in SHP1 the mean adj $\mathrm{R}^{2}$ is 34.4 and the mean of disaggregated book value is 42.3. On the basis of the above result, the null hypothesis is rejected while the alternative hypothesis is accepted with the conclusion that disaggregated book value is more value relevant compared to bottom line book value.

\subsubsection{Discussion of Findings}

Hypothesis 1 tested the incremental value relevance of decomposed earnings compared to value relevance of bottom line earnings. Using model 1 and 2 in which earnings are decomposed into the components parts, we compared value relevance measured by adj $\mathrm{R}^{2}$ of both bottom line earnings and decomposed earnings. Using each estimation technique, disaggregated earnings impact on value relevance was consistent in all indicating that disaggregated earnings are incrementally value relevant to bottom line earnings. The hypothesis of incremental value relevance of disaggregated earnings beyond bottom line earnings is accepted with finding consistent with Ibrahim et al (2005) and Apergis and Sorros (2009)

Hypothesis 2 tested the incremental value relevance of disaggregated book value of equity relative to bottom line book value of equity. Using model 1 and 3 we compare the value relevance of $\mathrm{Adj}^{2}$ of bottom line book value and disaggregated book value. On all four estimation methods, and on the average, disaggregated book value was consistently incrementally value relevant to bottom line book value of equity. The finding of this study placed in the 
context of an emerging market of Nigeria, presently, has no theory to determine the time taken for accounting information to be impounded in share price.

\section{Conclusions and Remarks}

The primary motivation of this study derives from the evidence adduced for declining value relevance of accounting information over the last 40 years by such studies as Dontoh, Radhakrishnan, and Ronen (2004) and Cortijo et al (2006). One reason adduced for this decline was the transformation of economies from industrial economies to service economies. Another reason adduced for the decline in value relevance by Kothari (2001) was the aggregation of accounting information. Based on these motivations, this study set out to examine the incremental value relevance of disaggregated accounting information over aggregated bottom line accounting information, using the Ohlson (1995) model and variants of the model, the four variants of regression estimation techniques and a methodology to accommodate the information inefficiency of the Nigerian Stock Exchange. The dependent variable of share price was employed at two different time intervals, 3 months and 6 months after the firm's year end. This was to allow for time for the market to fully impound accounting information in asset prices. Findings indicate that disaggregated earnings are incrementally value relevant beyond bottom line earnings. Also disaggregated book value is found to be more value relevant compared to book value. The issue of declining value relevance of accounting information as the economies continue their transformation continue to find support. Our study however indicates that using disaggregated accounting information seems to mitigate this problem. We recommend for both investors and analysts to shift emphasis from bottom line accounting information like earnings and book value to disaggregated accounting numbers to improve the quality of investment decisions they make. Besides, regulatory authorities must improve on the corporate governance environment in order to mitigate incidences of window dressing, creative accounting and other corporate malfeasances

\section{References}

Aboody, D., Hughes, J., \& Liu.J (2001). Measuring value relevance in a (possibly) inefficient market. Journal of Accounting research. 40(4), 965-98. http://dx.doi.org/10.1111/1475-679X.00078

Adaramola. A.O., \& Oyerinde, A.A. (2014). The relationship between financial accounting information and market values of quoted firms in Nigeria. Global Journal of Contemporary Research in Accounting, Auditing and Business Ethics. 1(1) 22:39.

Aspergis, N \& Sorros, J. (2009). The role of disaggregated earnings for stock prices: evidence from listed shipping firms and panel test. Research in Applied Economics. 1(1).1-24.

Babalola, Y.A. (2012). Significance of accounting information on corporate value of firms in Nigeria. Research Journal in organisational psychology and education studies, 1(20), 105-113.

Ball, R., \& Brown, P. (1968). An empirical examination of accounting income numbers. Journal of Accounting Research, 6(2), 159-178. http://dx.doi.org/10.2307/2490232

Ballas, A. (1996). The information content of the components of earnings: cross sectional evidence from the Ohlson model, being a paper presented at the $19^{\text {th }}$ annual congress of the EAA, Bergen.

Barth, M. E., \& G. Clinch, (1996). International accounting differences and their relation to share prices: Evidence from U.K., Australian, and Canadian Firms. Contemporary Accounting Research, 13(1), 135-170. http://dx.doi.org/10.1111/j.1911-3846.1996.tb00495.x

Beaver, W.H. (1968). The Information Content of Annual Earnings Announcements." Journal of Accounting Research, 6, 67-92. http://dx.doi.org/10.2307/2490070

Beaver, W.H. (2002). Perspective on recent capital market research. Accounting, 77(2), 453-474. http://dx.doi.org/10.2308/accr.2002.77.2.453

Bodnar, G.M. , \& Weintrop, J. (1997). The valuation of the foreign income of US multinational firms: a growth opportunities perspective. Journal of Accounting and Economics, 24(1), 69-97. http://dx.doi.org/10.1016/S0165-4101(97)00016-5

Chen, S., \& Wang, Y. (2004). Evidence from china on value relevance of operating income versus below-the-line items. International Journal of Accounting. 39(4), 339-364. http://dx.doi.org/10.1016/j.intacc.2004.06.012

Choi, Y.S, Lin, S., Walker, M. \& Young, S. (2007). Disagreement over persistence of earnings components: Evidence on the properties of management-specific adjustment to GAAP earnings. Review of Accounting Studies, 12(4), 595-622. http://dx.doi.org/10.1007/s11142-007-9048-x 
Dhaliwal, D., Subramanyan, K.R. , \& Trezevant, R. (1999). Is comprehensive income superior to net income as a measure of firm performance?. Journal of Accounting and Economics, 26(1), 43-67. http://dx.doi.org/10.1016/S0165-4101(98)00033-0

Dung, N.V. (2010). Value relevance of financial statement information. A flexible application of modern theories to the Vietnam stock market, being a paper presented at the development and policies research center, Vietnam

Hellstrom, K. (2006). The value relevance of financial accounting information in a transition economy: The case of the Czech Republic. European Accounting Review, 15(3), 325-349. http://dx.doi.org/10.1080/09638180600916242

Ibrahim, M.K., Raudah, D., Haslinda, Y,. \& Yatim, N. (2002). Market value and balance sheet numbers: Evidence from Malaysia. Asian Review of Accounting, 10(1), 77-88. http://dx.doi.org/10.1108/eb060750

Kwon, G. (2009). The value relevance of book values, earnings and cash flows: evidence from Korea. International Journal of Business and Management, 4(10), 28-43. http://dx.doi.org/10.5539/ijbm.v4n10p28

Landsman, W. (1986). An empirical investigation of pension fund property rights. The Accounting Review, 61(4), 44-68.

Landsman, W.R., Miller, B.L. \&\& Yeh, S. (2007). Implications of components of income excluded from pro forma earnings for future profitability and equity valuation. Journal of Business Finance and Accounting, 34(April/May), 650-75. http://dx.doi.org/10.1111/j.1468-5957.2007.02033.x

Lev, B., \& Thiagarajan, S.R. (1993). Fundamental information analysis. Journal of Accounting Research, 3(12), 190-215. http://dx.doi.org/10.2307/2491270

Ling, C.J. \& Yao, M.L. (2005). The value relevance of financial and non-financial information : evidence from Taiwan's information electronics industry, Review of Quantitative Finance and Accounting, 24(2), 135-157. http://dx.doi.org/10.1007/s11156-005-6334-1

Lopes, A.B. (2003). The value relevance of Brazillian accounting numbers; An empirical investigation. working paper. eaesp - Fundacao Geetulio Vargas.

Melissa, A.N. (2013). Value relevance of financial statement information: Evidence from listed firms in Kenya. Advances in Management and Applied Economics. 3(1), 115-134.

Ohlson, J.A. , \& Penman, S.H. (1992). Disaggregated accounting data as explanatory variables for returns. Journal of accounting, audit and finance. 7(4), 553-573.

Osamwonyi, I.O. , \& Anikamadu, M.O. (2002). The Nigerian stock market, efficient market hypothesis and the run test. Nigeria Journal of Business Administration, 4 (2), 30-53.

Osaze, E.B. (2007), The Nigerian capital market in the African and global financial system. Lagos: Bofic Consulting Group.

Pope, P.F. (2005). Discretionary accruals, accounting-based valuation models and the prediction of equity values. Journal of Accounting, Audit and Finance. 20(4), 347-354.

Ramakrishnan, R.T.S. , \& Thomas, J.K. (1998). Valuation of permanent, transistory, and price irrelevant components of reported earnings. Journal of Accounting, Audit and Finance. 13(3), 301-36.

Shehzad, K \& Ismail, A. (2014). Value relevance of accounting information and its impact on stock prices: case study of listed banks at the Karachi Stock Exchange. Journal of Economic Information. 3(1). 40-49.

Thomas, W.B. (2005). A test of market's mispricing of domestic and foreign earnings. Journal of Accounting and Economics. 28, 243-67. http://dx.doi.org/10.1016/S0165-4101(00)00007-0

$\mathrm{Xu}$, L. \& Cai, F. (2005). The valuation of high-tech "New Economy” companies. Journal of Global Competitiveness. $13(1 \& 2), 1-8$. 